\title{
Construction of Overexpression Vectors and Purification of the Oxygenase Component of Alkylphenol Hydroxylase of Pseudomonas alkylphenolia
}

\author{
Kyoung Lee \\ Department of Microbiology and Biomedical Science Institute at CWNU, Changwon National University,
}

Changwon 641-773, Republic of Korea

\section{Pseudomonas alkylphenolia의 알킬페놀 산화효소의 과발현 벡터 제작 및 단백질 정제}

\author{
이 경 \\ 창원대학교 미생물학과 및 생명의과학연구원 \\ (Received February 4, 2013 / Accepted March 4, 2013)
}

\begin{abstract}
Following construction of expression vectors in Escherichia coli, a new procedure involving two-step column purifications with a Fast Performance Liquid Chromatography System was developed for purification of the oxygenase component of alkylphenol hydroxylase of Pseudomonas alkylphenolia. From 50 g wet cake of recombinant $E$. coli BL21(DE3)(pJJPMO2) cells, $110 \mathrm{mg}$ of pure protein in a heterodimeric form containing a stoichiometric amount of iron were obtained and it exhibited a specific activity of $147 \mathrm{nmole} / \mathrm{min} / \mathrm{mg}$.
\end{abstract}

Keywords: Pseudomonas alkylphenolia, alkylphenol hydroxylase, bacterial multicomponent monooxygenase (BMM), diiron cluster

Pseudomonas alkylphenolia KL28 (KCTC22206) is a Gram-negative bacterium that can utilize alkylphenols with an alkyl group $\left(\mathrm{C}_{1}-\mathrm{C}_{5}\right)$ at para or meta position as sole source of carbon and energy (Jeong et al., 2003; Lee and Veeranagouda, 2009; Cho et al., 2011). A gene cluster consisting of 14 genes, named as lap, responsible for the catabolism was previously identified (Jeong et al., 2003). The homologies of deduced amino acid sequences and functional studies with subclones showed that lapKLMNOP encode alkylphenol hydroxylase $(\mathrm{aPH})$. Substrate specificity studies showed that $\mathrm{aPH}$ preferentially oxidizes 3- and 4-alkylphenols to 4-alkylcatechols (Jeong et al., 2003). In addition, the deduced amino acid sequences of lapKLMNOP exhibit high similarities (43-60\%) to those of well-studied $d m p K L M N O P$ genes that encode dimethylphenol hydroxylase (dimethyl $\mathrm{PH}$ ) from Pseudomonas sp. CF600 (Shingler et al., 1992). The latter enzyme catalyzes hydroxylation of phenol and dimethylphenols to respective

*For correspondence. E-mail: kyounglee@changwon.ac.kr; Tel.: +82-55213-3486; Fax:+82-55-213-3480 catechols and consists of three components, reductase (DmpP), modulator (DmpM), and oxygenase (DmpLMO) (Shingler et al., 1992). Reductase (about $42 \mathrm{kDa}$ ) contains FAD and $2 \mathrm{Fe}-2 \mathrm{~S}$ as cofactors and mediates electron transfer from $\mathrm{NADH}$ to oxygenase component. Modulator protein (about $10 \mathrm{kDa}$ ) is required for maximal catalytic activity of substrate hydroxylation (Cadieux and Powlowski, 1999). The oxygenase component at a quaternary structure of $(\alpha \beta \gamma)_{2}$ with a calculated molecular mass of $220 \mathrm{kDa}$ contains a $\mathrm{Fe}-\mathrm{O}-\mathrm{Fe}$ diiron center at the active site and catalyzes hydroxylation reactions in consumption of $\mathrm{O}_{2}$ and electrons provided by reductase (Cadieux et al., 2002). The DmpK has been shown to play a role in assembly of the active form of the oxygenase component of dimethyl PH (Powlowski et al., 1997). According to the known biochemical functions of the components of dimethyl $\mathrm{PH}$, homologous functions of the Lap proteins in $P$. alkylphenolia can be envisaged as shown in Fig. 1. Dimethyl PH and aPH belong to a family of BMMs (bacterial multicomponent monooxygenases) which possess characteristic features with a diiron (III) catalytic active site coordinated by four glutamate and two histidine ligands (Sazinsky 
and Lippard, 2006). The BMM members consist of short electron transport components. BMMs play a key role in global methane cycling and biodegradation of toxic compounds (Notomista et al., 2003). Thus, the full understanding of BMMs at biochemical levels will aid in solving related global environmental problems. To date, PHs showing activities towards only simple phenols have been purified and characterized from Pseudomonas sp. CF600 (Cadieux et al., 2002), Acinetobacter radioresistens S13 (Divari et al., 2003) and Pseudomonas stutzeri OX1 (Sazinsky et al., 2006). In this study, a method for mass purification of the oxygenase component of aPH from recombinant $E$. coli cells expressing lap genes was developed for further studies such as biochemical and crystallographic characterization.

Because the previously constructed aPH expression vector pJJPMO2 is based on a weak promoter pBBR1MCS-5 (Jeong et al., 2003), a new vector was constructed for higher expression of aPH as follows. The DNA fragment (854 bp) encoding partial lapN and lapO was PCR-amplified with primers lapO-HindIII (5'-CACATCAAGAAGCTTGAAGCG3', HindIII underlined) and lapP-XbaI (C5'-TTCGATCTAGAT GGTCAGACA-3', XbaI underlined). The PCR product was cloned into HindIII/XbaI in pK19 (Schafer et al., 1994) and the nucleotide sequence was confirmed. The constructed vector was named as pJJO. The rest of aPH genes was retrieved by digestion of pJJPMO2 (Jeong et al., 2003) with HindIII/KpnI and the resulting 3,060-bp fragment was cloned into pJJO at the same restriction sites. A $K p n \mathrm{I} / X b a \mathrm{I}(3.9 \mathrm{~kb})$ fragment from the constructed vector (pJJPH1) was again cloned into pTrc99A which contains a strong ptrc promoter (Amann et al., 1988) forming pJJPH2 (Fig. 2). The reductase overexpression vector was constructed by cloning the $2.7-\mathrm{kb} H i n d I I I-E c o$ RI DNA fragment of pJJPMO2 into the same sites of pT7-6 (Tabor, 2001) and was named pJJOP2 (Fig. 2). The alkylcatechol dioxygenase (LapB) overexpression vector (pJJC23O2) (Fig. 2) was constructed by cloning of $l a p B$ gene from the previously constructed pJJC23O (Jeong et al., 2003) into SalI/SacI sites of pT7-6. The expression vector (pJJKLM2) of both lapK and lapM genes was made by deletion of a $2.8-\mathrm{kb}$ PstI fragment in

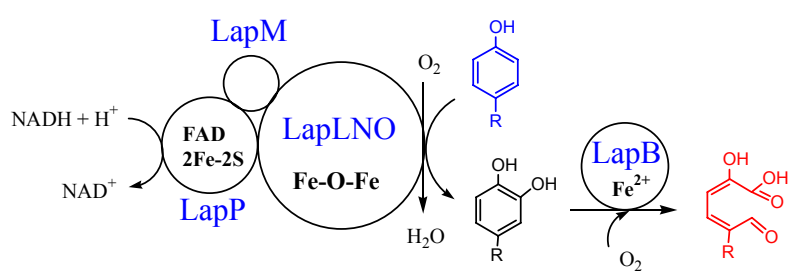

Fig. 1. Diagram showing reactions catalyzed by aPH (LapMPLNO) and alkylcatechol dioxygenase (LapB) yielding a ring-fission product from alkylphenol. The cofactors included in enzymes are also indicated.
pJJPH2 (Fig. 2). The vectors were transformed into E. coli BL21(DE3) and appropriate antibiotic was added for maintaining plasmids in cells.

To make cell-free extracts necessary for sources of enzyme assay, E. coli BL21(DE3) strains with plasmids were grown in LB with ampicillin $(0.1 \mathrm{mg} / \mathrm{ml})$ overnight at $30^{\circ} \mathrm{C}$, and from the seed $1 \mathrm{ml}$ was inoculated into $100 \mathrm{ml} \mathrm{LB}$ medium with ampicillin contained in a 500-Erlenmeyer flask. Following $3 \mathrm{~h}$ shaking incubation, isopropyl $\beta$-D-1-thiogalactopyranoside (IPTG, final concentration of $0.4 \mathrm{mM}$ ) and ampicillin were added and cultured for 3 more h. Following cultivation, cells were harvested by centrifugation and $1.4 \mathrm{ml}$ of TG buffer (50 $\mathrm{mM}$ Tris- $\mathrm{HCl}, 5 \%$ glycerol, $\mathrm{pH}$ 7.0) was added and sonicated for $30 \mathrm{sec}$. Following centrifugation at $4^{\circ} \mathrm{C}$, the cell extracts in $50 \mu \mathrm{l}$-aliquots were stored at $-72^{\circ} \mathrm{C}$ and were used when necessary. For mass cultivation of $E$. coli BL21(DE3)(pJJPH2), NEB Bioflo fermentor (9 L) was used. Cells were cultured in a modified LB medium consisting of $\mathrm{NaCl} 45 \mathrm{~g}$, yeast extract $90 \mathrm{~g}$, tryptone $90 \mathrm{~g}$, ferrous ammonium sulfate $0.45 \mathrm{~g}$, ampicillin $1.35 \mathrm{~g}$ at $30^{\circ} \mathrm{C}, 450 \mathrm{rpm}$ and $4 \mathrm{vvm}$ aeration. Following $2 \mathrm{~h}$ fermentation, $1 \mathrm{~g}$ IPTG and $1.35 \mathrm{~g}$ ampicillin were added again and culture was continued until a turbidity of 6.6 at $\mathrm{OD}_{600}$. After that, cells were harvested by centrifugation and about $100 \mathrm{~g}$ of wet cake was obtained. The harvested cells were suspended in $100 \mathrm{ml}$ TG buffer and $50 \mathrm{ml}$ aliquots were stored at $-72^{\circ} \mathrm{C}$ until use.

Enzyme activity was quantitated using a coupled assay where 4-methylcatechol formed by aPH from substrate $m$-cresol was converted to a yellow-colored ring fission product in the presence of LapB (Cho et al., 2009) (Fig. 1). The assay mixture $(250 \mu \mathrm{l})$ contained in $20 \mathrm{mM}$ Tris- $\mathrm{HCl}$ (pH 7.0), E. coli BL21(DE3)(pJJC23O2) cell-free extract (alkylcatechol dioxygenase source, $5 \mu \mathrm{l}$ ), E. coli BL21(DE3)(pJJOP2) cell-free extract (reductase source, $10 \mu \mathrm{l}$ ), oxygenase source (variable amount) and $2.5 \mu \mathrm{l}$

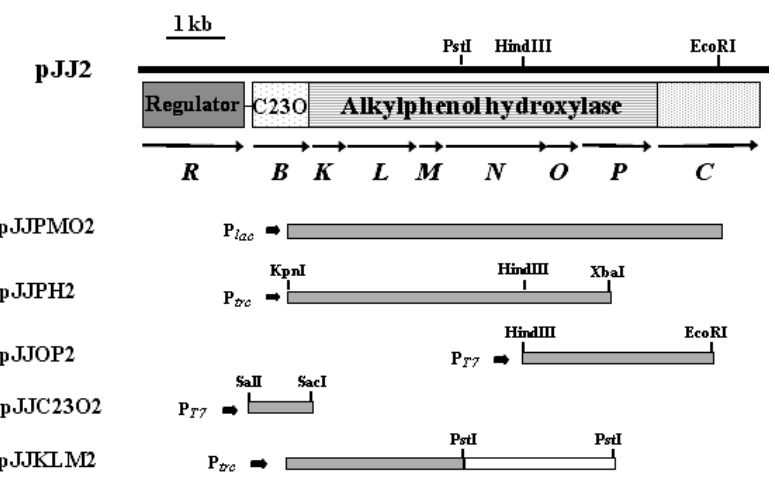

Fig. 2. Genetic maps of a lap gene cluster and lap gene expression vectors. The promoters controlling the expression of the gene(s) are also indicated. $\mathrm{C} 23 \mathrm{O}$ is for alkylcatechol dioxygenase. Plasmids $\mathrm{pJJ} 2$ and pJJPMO2 were previously described (Jeong et al., 2003). The deleted portion from pJJPH2 is white-boxed in creation of pJJKLM2. 
Table 1. Purification steps of the oxygenase component of aPH

\begin{tabular}{|c|c|c|c|c|c|}
\hline & $\begin{array}{l}\text { Pooled volume } \\
(\mathrm{ml})\end{array}$ & $\begin{array}{l}\text { Protein concentration } \\
(\mathrm{mg} / \mathrm{ml})\end{array}$ & $\begin{array}{l}\text { Total protein } \\
(\mathrm{mg})\end{array}$ & $\begin{array}{l}\text { Activity } \\
\text { (U) }\end{array}$ & $\begin{array}{c}\text { Specific activity } \\
(\mathrm{mU} / \mathrm{mg} \text { of LapLNO })^{\mathrm{a}}\end{array}$ \\
\hline Crude cell extract & 120 & 72 & 8,640 & $-{ }^{b}$ & - \\
\hline Q sepharose & 105 & 7.2 & 756 & 81 & 107 \\
\hline Octyl sepharose & 2.1 & 52.5 & 110 & 16.2 & 147 \\
\hline
\end{tabular}

of $0.1 \mathrm{M} \mathrm{m}$-cresol dissolved in methanol. The activity was measured in a kinetic mode of a spectrophotometer (Beckman Co.) by addition of $5 \mu \mathrm{l}$ of $0.1 \mathrm{M} \mathrm{NADH}$. The increase of absorbance at $420 \mathrm{~nm}$ was monitored for $30 \mathrm{sec}$. The slope was used for calculation of the activity with $\mathrm{e}_{420 \mathrm{~nm}}=14 \mathrm{mM}^{-1} \mathrm{~cm}^{-1}$ (Jeong et al., 2003).

To make a crude cell extract, $50 \mathrm{~g}$ of wet cake of $E$. coli BL21(DE3)(pJJPH2) was thawed by addition of $40 \mathrm{ml}$ of TG buffer with $1 \mu \mathrm{g} / \mathrm{ml}$ DNase and was lysed by a Frech pressure as previously described (Lee et al., 1997). The crude cell extract was applied to a Q-Sepharose FF column (GE Healthcare, $5 \times 20 \mathrm{~cm}$ ) previously equilibrated with TG buffer. The column was washed with $200 \mathrm{ml}$ of TG buffer at a flow rate of 2 $\mathrm{ml} / \mathrm{min}$ and then bound oxygenase was eluted with a $2,100 \mathrm{ml}$ linear $\mathrm{KCl}$ gradient $(0-0.5 \mathrm{M})$ in TG buffer. Fractions $(28 \mathrm{ml})$ were collected and assayed for aPH activity. Fractions (78-76) were pooled and concentrated to $105 \mathrm{ml}$ over an Amicon YM100 membrane by ultrafiltration. Solid ammonium sulfate (115 g) was slowly added to the solution with stirring. Following centrifugation, the supernatant was applied to a column $(2.6 \times$ $26 \mathrm{~cm}$ ) of Octyl sepharose CL-4B (GE Healthcare) equilibrated with $1 \mathrm{M}$ ammonium sulfate. Oxygenase was eluted with a 450 $\mathrm{ml}$ linear gradient of decreasing ammonium sulfate $(1.0-0.0$ M). Fractions $(5 \mathrm{ml})$ were collected and active fractions (113115) were pooled and washed with TG buffer by ultrafiltration. Purified oxygenase was drop frozen in liquid nitrogen in $25 \mu \mathrm{l}$

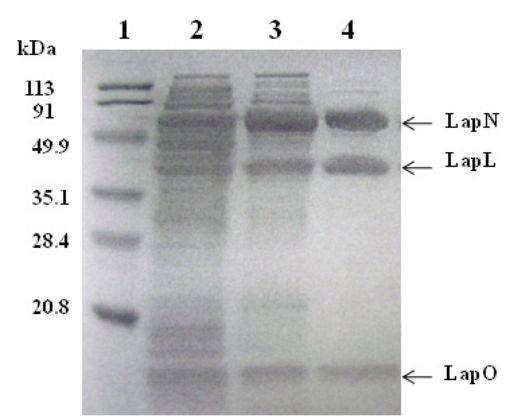

Fig. 3. $12 \%$ SDS-PAGE gel showing proteins at each purification step. Lanes: 1, size markers (Bio-Rad); 2, crude cell extract $40 \mu \mathrm{g}$; 3, Q-sepharose pool $20 \mu \mathrm{g}$; 4, Octyl sepharose pool $10 \mu \mathrm{g}$. aliquots and the protein pellets were stored at $-72^{\circ} \mathrm{C}$ until use. Protein was purified using a FPLC system (Bio-Rad) at $4{ }^{\circ} \mathrm{C}$.

From the purification, $110 \mathrm{mg}$ of oxygenase with a specific activity of $147 \mathrm{nmole} / \mathrm{min} / \mathrm{mg}$ was obtained from 8,640 mg of cell-free extract proteins (Table 1). The activity of the finally purified oxygenase was independent of the addition of cell-free extract of E. coli BL21(DE3)(pJJKLM2), a source of LapK and LapM. The homologous proteins DmpK and DmpM are known to functioning in assembly of active dimethyl $\mathrm{PH}$ and in stimulating (more than 10 times) the activity of substrate hydroxylation, respectively (Powlowski et al., 1997; Cadieux and Powlowski, 1999). In addition, DmpM has been reported to be inactive when expressed in E. coli (Cadieux and Powlowski, 1999). For these reasons, addition of cell-free extract containing LapK and LapM could have no effects on aPH activity. The specific activity of purified oxygenase is higher compared to that of dimethyl $\mathrm{PH}$ which showed a specific activity of about $50 \mathrm{nmole} / \mathrm{min} / \mathrm{mg}$ in the absence of the modulator component (Cadieux et al., 2002).

The purified oxygenase of aPH exhibited a pale green color due to the presence of diiron clusters at the active site and showed three bands at the expected mass sizes of 58.9, 41.1, and $13.2 \mathrm{kDa}$ in denaturing SDS-PAGE (Fig. 3). No other distinctive contamination bands were observed. The native molecular weight of the protein was estimated to be approximately 220 $250 \mathrm{kDa}$ from gel permeation chromatography when determined

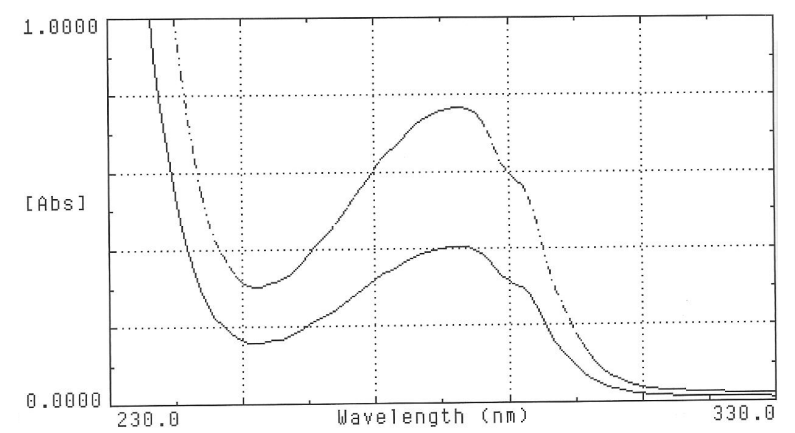

Fig. 4. UV-Vis spectra of the purified oxygenase component of aPH. Upper and lower spectra are with 0.525 and $0.26 \mathrm{mg} / \mathrm{ml}$ protein, respectively. 
by the method previously described (Haddock and Gibson, 1995). Thus, oxygenase appears to exist as a dimer form, consistent to the crystal structures of BMM $\mathrm{PH}$ and toluene/o-xylene monooxygenase hydroxylase from Pseudomonas stutzeri OX1 (Sazinsky et al., 2004, 2006). The UV-Visible spectrum of purified oxygenase showed a peak at $281 \mathrm{~nm}$ (Fig. 4). The calculated $\mathrm{e}_{281 \mathrm{~nm}}$ was $1.95 \times 10^{5} \mathrm{M}^{-1} \mathrm{~cm}^{-1}$ based on a dimer form. A shoulder was observed at $291 \mathrm{~nm}$, a characteristic of these proteins, indicating a high purity since contamination of other proteins would shield the shoulder absorbance. The estimated iron content was 1.85 mole per $\alpha \beta \gamma$ mole as determined by the method previously described (Haddock and Gibson, 1995) and addition of ferrous iron in the assay did not stimulate the activity, indicating almost a stoichiometric amount of iron was bound as a diiron cluster at the active sites of the purified oxygenase. The purified active oxygenase is currently exploited for crystal formation to characterize aPH BMM with unique substrate selectivity and regiospecificity. From the results, aPH can be further modified to increase specific activities and change the substrate specificity towards octyl- and nonylphenols, endocrine disrupting chemicals, and to produce value-added alkylcatechols.

\section{적 요}

본 연구에는 대장균에서의 과발현 벡터 개발과 FPLC를 사용 한 2단계 컬럼 정제과정을 통해 Pseudomonas alkylphenolia의 alkylphenol hydroxylase의 oxygenase 단백질을 다량으로 정제 하는 방법을 개발하였다. 재조합 Escherichia coli BL21(DE3) (pJJPMO2)의 $50 \mathrm{~g}$ 의 wet cake로부터 $110 \mathrm{mg}$ 의 heterodimer이 며 화학량론적 철을 갖는 순수한 단백질을 정제하였으며 147 $\mathrm{nmole} / \mathrm{min} / \mathrm{mg}$ 의 비활성을 보였다.

\section{Acknowledgements}

This research is financially supported by Changwon National University in 2011-2012. The author would like to thank Prof. David T. Gibson (Univ. of Iowa, USA) for his help during this experiment.

\section{References}

Amann, E., Ochs, B., and Abel, K.J. 1988. Tightly regulated tac promoter vectors useful for the expression of unfused and fused proteins in Escherichia coli. Gene 69, 301-315.

Cadieux, E. and Powlowski, J. 1999. Characterization of active and inactive forms of the phenol hydroxylase stimulatory protein DmpM. Biochemistry 38, 10714-10722.

Cadieux, E., Vrajmasu, V., Achim, C., Powlowski, J., and Munck, E. 2002. Biochemical, MÖssbauer, and EPR studies of the diiron cluster of phenol hydroxylase from Pseudomonas sp. strain CF 600 .
Biochemistry 41, 10680-10691.

Cho, J.H., Jung, D.K., Lee, K., and Rhee, S. 2009. Crystal structure and functional analysis of the extradiol dioxygenase LapB from a long-chain alkylphenol degradation pathway in Pseudomonas. $J$. Biol. Chem. 284, 34321-34330.

Cho, A.R., Lim, E.J., Veeranagouda, Y., and Lee, K. 2011. Identification of a $p$-cresol degradation pathway by a GFP-based transposon in Pseudomonas and its dominant expression in colonies. J. Microbiol. Biotechnol. 21, 1179-1183.

Divari, S., Valetti, F., Caposio, P., Pessione, E., Cavaletto, M., Griva, E., Gribaudo, G., Gilardi, G., and Giunta, C. 2003. The oxygenase component of phenol hydroxylase from Acinetobacter radioresistens S13. Eur. J. Biochem. 270, 2244-2253.

Haddock, J.D. and Gibson, D.T. 1995. Purification and characterization of the oxygenase component of biphenyl 2,3-dioxygenase from Pseudomonas sp. strain LB400. J. Bacteriol. 177, 5834-5839.

Jeong, J.J., Kim, J.H., Kim, C.K., Hwang, I., and Lee, K. 2003. 3- and 4-alkylphenol degradation pathway in Pseudomonas sp. strain KL28: genetic organization of the lap gene cluster and substrate specificities of phenol hydroxylase and catechol 2,3-dioxygenase. Microbiology 149, 3265-3277.

Lee, K., Kauppi, B., Parales, R.E., Gibson, D.T., and Ramaswamy, S. 1997. Purification and crystallization of the oxygenase component of naphthalene dioxygenase in native and selenomethionine-derivatized forms. Biochem. Biophys. Res. Commun. 241, 553-557.

Lee, K. and Veeranagouda, Y. 2009. Ultramicrocells form by reductive division in macroscopic Pseudomonas aerial structures. Environ. Microbiol. 11, 1117-1125.

Notomista, E., Lahm, A., Di Donato, A., and Tramontano, A. 2003. Evolution of bacterial and archaeal multicomponent monooxygenases. J. Mol. Evol. 56, 435-445.

Powlowski, J., Sealy, J., Shingler, V., and Cadieux, E. 1997. On the role of DmpK, an auxiliary protein associated with multicomponent phenol hydroxylase from Pseudomonas sp. strain CF600. J. Biol. Chem. 272, 945-951.

Sazinsky, M.H., Bard, J., Di Donato, A., and Lippard, S.J. 2004. Crystal structure of the toluene/o-xylene monooxygenase hydroxylase from Pseudomonas stutzeri OX1. Insight into the substrate specificity, substrate channeling, and active site tuning of multicomponent monooxygenases. J. Biol. Chem. 279, 30600-30610.

Sazinsky, M.H., Dunten, P.W., McCormick, M.S., DiDonato, A., and Lippard, S.J. 2006. X-ray structure of a hydroxylase-regulatory protein complex from a hydrocarbon-oxidizing multicomponent monooxygenase, Pseudomonas sp. OX1 phenol hydroxylase. Biochemistry 45, 15392-15404.

Sazinsky, M.H. and Lippard, S.J. 2006. Correlating structure with function in bacterial multicomponent monooxygenases and related diiron proteins. Acc. Chem. Res. 39, 558-566.

Schafer, A., Tauch, A., Jager, W., Kalinowski, J., Thierbach, G., and Puhler, A. 1994. Small mobilizable multi-purpose cloning vectors derived from the Escherichia coli plasmids pK18 and pK19: selection of defined deletions in the chromosome of Corynebacterium glutamicum. Gene 145, 69-73.

Shingler, V., Powlowski, J., and Marklund, U. 1992. Nucleotide sequence and functional analysis of the complete phenol/3,4-dimethylphenol catabolic pathway of Pseudomonas sp. strain CF600. J. Bacteriol. 174, 711-724.

Tabor, S. 2001. Expression using the T7 RNA polymerase/promoter system. Curr. Protoc. Mol. Biol. 11, 16.12.11-16.12.11. 